\title{
RESEARCH REGARDING THE PARTIAL REPLACEMENT OF AGGREGATES IN CONCRETE WITH A BY-PRODUCT OF STEEL INDUSTRY
}

\author{
Liliana ANDONE, Andrada Gabriela ALEXANDRU, Marius BODOR* \\ "Dunarea de Jos" University of Galati, Romania \\ e-mail:*marius.bodor@ugal.ro
}

\begin{abstract}
A continuous increase in demand for natural resources, in a high proportion for the construction sector, creates the necessity to search for alternatives. This work is intended to do so and the aim is the replacement of natural aggregates in some concrete samples with a metallurgical industry by-product. The replacement was gradual and only for one type of the three dimensions utilized. The results of the many tests conducted revealed the possibility of natural aggregate replacement in some extent, keeping the resulted properties of samples within the limits of the standards.
\end{abstract}

KEYWORDS: cement; concrete; aggregate; steel slag; compressive strength

\section{Introduction}

In the last decades, different materials were used in concrete composition in order to utilize some industrial wastes or for reutilization of aggregates from demolitions. In the concrete composition, the aggregate represents an important share (at least 75\% from the concrete volume) and an important influence towards concrete properties. Although, at first, the aggregate was considered as an inert material, dispersed in the cement paste, today, the conception regarding the aggregate role in concrete is changed being regarded as a material linked in a cohesive whole through cement stone. The physical, thermic and sometimes the chemical properties of aggregates influence the concrete performances. Aggregate costs are much lower compared to the cement and thus, it is indicated for aggregate to be used as much as possible [1].

Different types of materials can work together with concrete or can participate in its structure, like industrial by-products or different wastes. Numerous studies were mainly focused on replacing the cement with different quantities of fly ash, slag or ultrafine silica [2]. Replacing the aggregate with industrial byproducts remained secondary since the price of this concrete component is lower.

In the first stage, aggregate replacement was done using metallurgical slags, in different compositions, for civil and hydrotechnical constructions or for roads. First tests, using these aggregate replacements satisfied mechanical strength imposed by the natural aggregate concretes yet it is necessary to deepen the studies on concrete types, being required tests specific to each concrete type [2].

For construction concretes, replacement of natural aggregates with slag aggregates leads to higher concrete densities, recommending these concretes in foundations or massive constructions (hydrotechnical constructions for example) thus, other analyses are imposed: permeability and freezing-thaw resistance [3].

Linz-Donawitz (LD) slag is a type of industrial by-product that was used as partial replacement of aggregate in a former study [4], and promising results were obtained. The burden of the mentioned study was the weathering of the industrial by-product through the process named carbonation with the purpose to diminish the $\mathrm{CaO}$ content, responsible for slag swelling in prolonged contact with water. Different studies regarding mineral carbonation of LD slag also occurred [5-8], and the process, although rapid and efficient remains costly. The present study aimed using an already marketed material obtained from the same LD slag, namely LiDonit.

LiDonit utilisation may offer great economic and ecological benefits. This product, which is a trademark of the German industrial group ThyssenKrupp, through its DSU division [9], is successfully used for roads and railroads construction in Europa, being legally approved in different countries for these purposes. Although it has a greater 
porosity than that of traditionally used natural aggregates, the LiDonit, with a special crystallinmineralogical composition, can compete with the hardest rocks regarding their wear, impact and compression resistance. Obtained by slag crushing, the LiDonit granules are polyhedral in shape, with sharp edges and corners and roughened faces. Also, the density which is $20 \%$ higher and in appearance seems a defect, helps this material to increase its autocompacting characteristic. All these features make this secondary product of the Linz-Donawitz process a material fit to be used especially in the construction of roads in all road layers [10].

The utilization of LiDonit in road construction is well documented [11] and already a success in many construction sites. This paper aims to present an alternative for the use of this material, namely as partial replacement of aggregate in concretes. Increasing the utilization of slag derived materials will drive the reduction of piled by-products from the steel industry and the impact to the environment along with it. In this regard, two concrete recipes were chosen, and five concentrations of natural aggregate-LiDonite mixtures for each type of the two concrete recipes. The final purpose was to demonstrate through relevant laboratory tests the optimal mixture of the LiDonit containing aggregate.

\section{Materials and methods}

\subsection{Aggregates}

The materials used as aggregates were divided in three sorts: $0 / 4 \mathrm{~mm} ; 4 / 8 \mathrm{~mm}$ and $8 / 16 \mathrm{~mm}$. The first two sorts used in this work were of natural provenience and since LiDonit is usually commercialised as coarse aggregate, in this study the replacement of natural aggregate was realised only for the $8 / 16 \mathrm{~mm}$ type sort (out of the three sorts considered). The grades of coarse aggregates must be determined by using the dimensions of the sieves presented in SREN 12620+A1: 2008. Thus, the general characteristics of the granulosity is expressed as a percentage of mass transfer of the aggregate with the respective tolerances presented in SREN 12620+A1: 2008 [12].

LD slag is formed during steel production using a technique developed in Linz and Donawitz (both in Austria). LiDonit is produced by adding silicates and oxygen to the still liquid slag to prevent possible expansion and guarantee stability. Under quality monitoring regulations, its construction- and environment-related parameters are subjected to regular internal and external checks to guarantee a high-quality building material product [13].

\subsection{Cements}

Two types of binders were used in this study, namely the CEM II A-V/42,5R and CEM III A$42,5 \mathrm{~N}-\mathrm{LH}$ class cements. Both types were obtained by using industrial wastes in their content, CEM II AV/42,5R type cement contains fly ash while CEM III/A 42,5 N-LH type cement contains granulated blast furnace slag, making the two concrete recipes used in this paper even more environmentally friendly. The selected binders are typically used in civil and industrial constructions, hydrotechnical constructions, roads, bridges et al. [14].

\subsection{Obtaining concrete samples}

The concrete samples were obtained by mixing cement, water, a superplasticizing additive and aggregates in fixed quantities except for water. Water quantity was varied so that the workability met the standards [14]. The variation of water to cement ration can be observed in Figure 1 and is represented for each concrete recipe using the two types of binders.

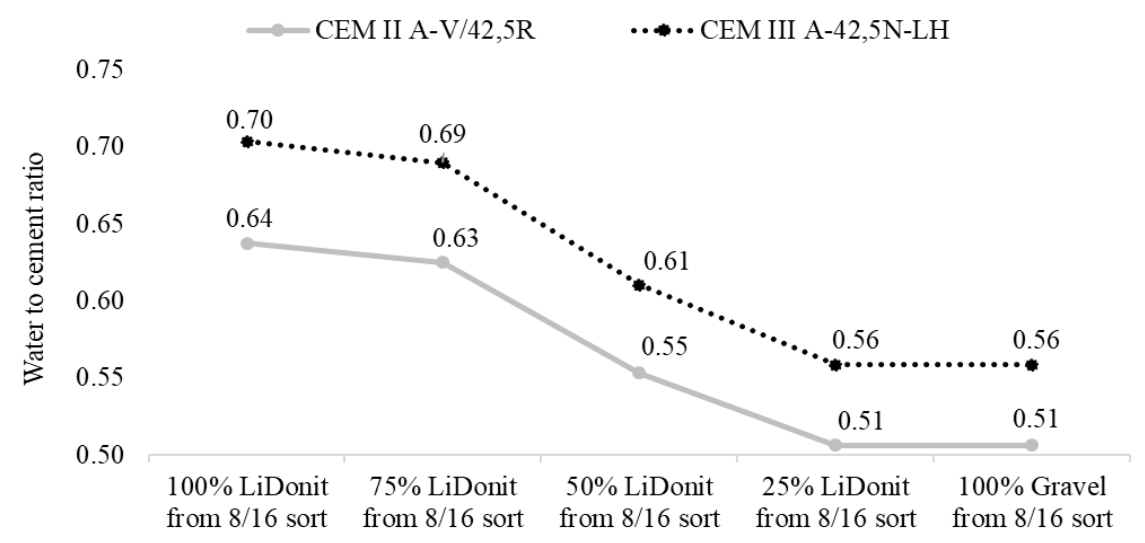

Fig. 1. Representation of water to cement ratio used for each concrete recipe 
Figure 1 also presents the weight percentage of LiDonit used to replace gravel (the $8 / 16 \mathrm{~mm}$ aggregate sort). Thus, as it is observable in the figure, five different recipes for each type of cement were chosen as follows: $100 \%, 75 \%, 50 \%$ respectively $25 \%$ LiDonit out of the $8 / 16 \mathrm{~mm}$ sort and $100 \%$ gravel as $8 / 16 \mathrm{~mm}$ aggregate sort.

\subsection{Testing procedures}

Different types of tests were used to analyse the aggregate mixtures and then each concrete recipe. Aggregate mixtures were tested from the granulometry, shape coefficient and degree of wear point of view, while concrete samples were analysed, before hardening, from the density and workability point of view. After hardening (curing), concrete samples were analysed regarding their compressive strength, impermeability and freezing-thaw resistance properties. All tests were conducted according to the existing norms [12, 14-41].

\section{Results and discussions}

Prior to concrete recipes formation, LiDonit containing aggregate mixtures were analysed and compared with all-natural aggregate mixtures using three above mentioned tests: granulometry, shape coefficient and degree of wear.

Granulometric curves according to CP 012/1-2007 norm

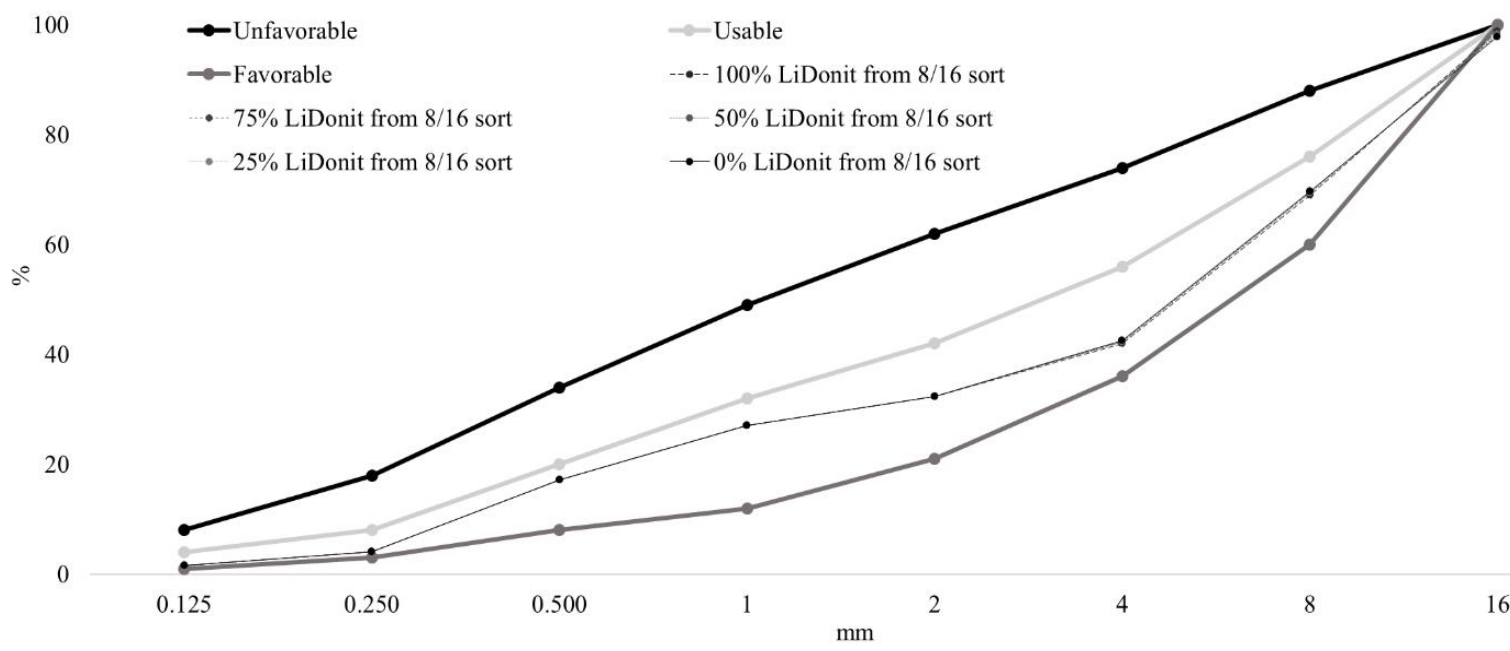

Fig. 2. Granulometric curves for all aggregate mixtures used in this study, compared to the unfavourable, usable and favourable limits, according to CP 012/1-2007 norm

From the first mentioned test results point of view, all mixtures, with small differences, are between usable and favourable curves, meaning that the granulometry of all aggregate mixtures is in accordance to the standards (Figure 2).

As for the shape coefficient results, Figure 3 presents the limit of this type of analysis set by the appropriate normative. The maximum for this test, namely $25 \%$, was exceeded only by the LiDonit $8 / 16$ $\mathrm{mm}$ sort, while for the $4 / 8 \mathrm{~mm}$ and $8 / 16 \mathrm{~mm}$ sorts the values were well below the admissible value. This test is important in order to determine mass of all plate and acicular granules from the analysed sample and the higher-then-admissible value for LiDonit 8/16 $\mathrm{mm}$ sort is not of great concern since the purpose of this work was to establish the optimal degree of natural aggregate replacement with this metallurgical by-product. If replacing $50 \%$ of the natural $8 / 16 \mathrm{~mm}$ aggregate sort with LiDonit of the same granulometry, the average value for the shape coefficient test would still be under the maximal admissible value set by the utilized standard.

The last test involving the aggregates used in this study was the one regarding the wear degree, using a Los Angeles type machine. The test results (Figure 4) showed a good behaviour of the LiDonit $8 / 16 \mathrm{~mm}$ aggregate sort, compared to the same sort of the natural provenience material, both samples recording results under the maximum $30 \%$ established by the standard.

Thus, the results from three tests used for the aggregates proves the viability to use the LiDonit material as partial replacement of natural aggregate in some concrete recipes. 


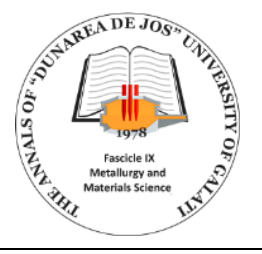

THE ANNALS OF “DUNAREA DE JOS” UNIVERSITY OF GALATI

FASCICLE IX. METALLURGY AND MATERIALS SCIENCE

No. 1 - 2020, ISSN 2668-4748; e-ISSN 2668-4756

Article DOI: https://doi.org/10.35219/mms.2020.1.02

Shape coefficient, according to SR EN 933-4 norm

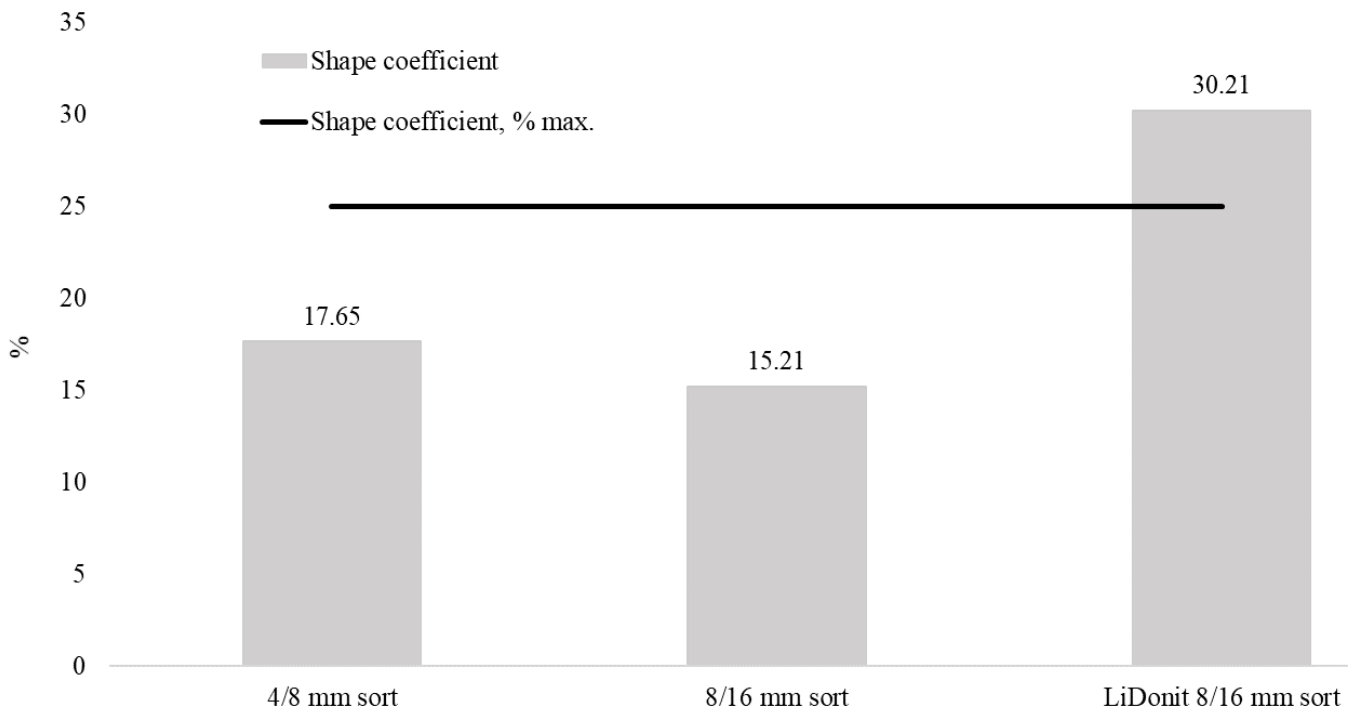

Fig. 3. Results of the shape coefficient test for $4 / 8 \mathrm{~mm}, 8 / 16 \mathrm{~mm}$ and LiDonit $8 / 16 \mathrm{~mm}$ sort, compared to the highest limit established through SR EN 933-4 norm

Degree of wear obtained with the Los Angeles type machine, according to SR 667 norm

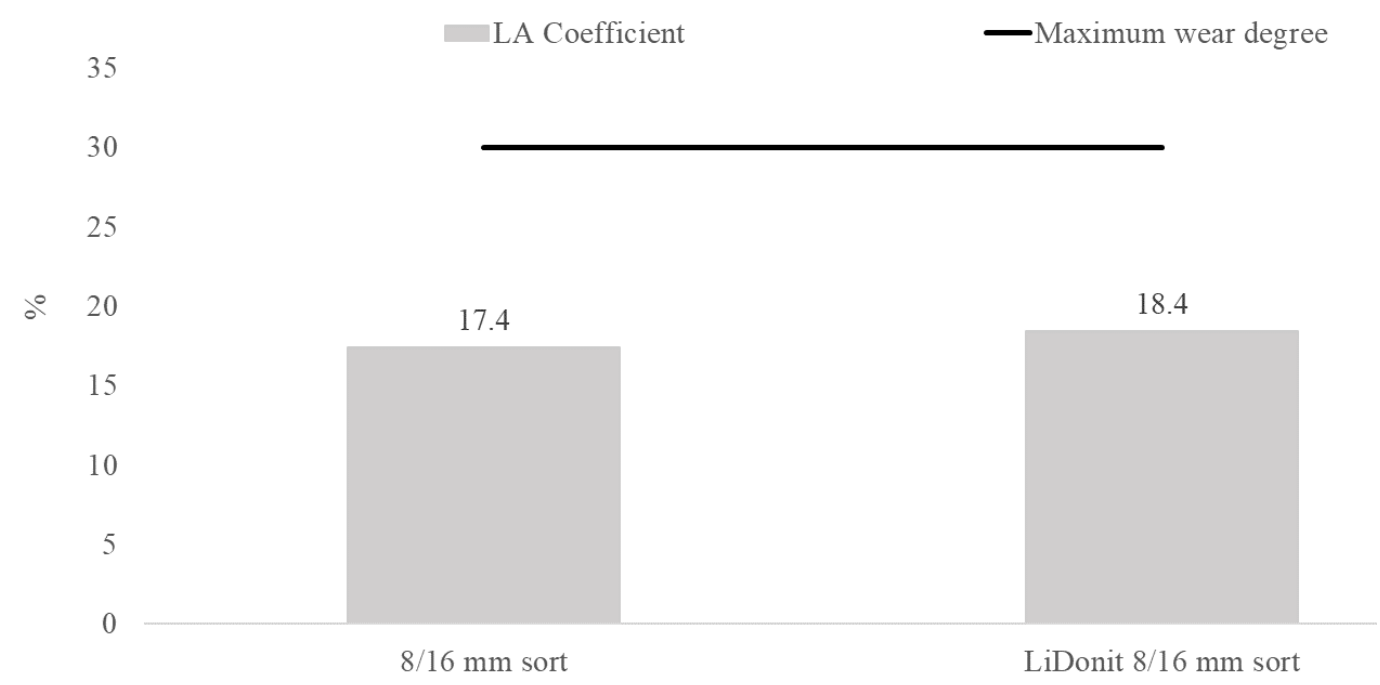

Fig. 4. Values from the wear degree of natural $8 / 16 \mathrm{~mm}$ and LiDonit 8/16 mm sorts obtained with the Los Angeles type machine and compared with the maximum admissible, according to the SR 667

norm

After mixing all components, before curing, the obtained samples were first tested form the workability and density point of view. Table 1 presents the results of workability test. Data for this type of test shows a variety of results depending on the LiDonit content. For samples obtained using the CEM II/A-V type cement, the values for workability increases with LiDonit content while for the samples obtained using the CEM III/A type cement, the values decrease with LiDonit content increase. LiDonit, being a porous material, is expected to cause workability decrease if used in higher quantities thus, data for samples obtained using CEM III/A type cement was expected. However, the exceeding of 50$150 \mathrm{~mm}$ required minimum is considered acceptable and may be attributed to the human error during sample preparation. The workability test results indicate that an aggregate replacement with LiDonit might be feasible at least for the $25-50 \%$ of the $8 / 16$ $\mathrm{mm}$ aggregate sort. 
Table 1. Results from the workability test for all mixtures

\begin{tabular}{|c|c|c|c|c|c|c|}
\hline CEM II/A-V & $\begin{array}{c}\text { 100\% LiDonit } \\
\text { from 8/16 sort }\end{array}$ & $\begin{array}{c}\text { 75\% LiDonit } \\
\text { from 8/16 sort }\end{array}$ & $\begin{array}{c}\mathbf{5 0 \%} \text { LiDonit } \\
\text { from 8/16 sort }\end{array}$ & $\begin{array}{c}\text { 25\% LiDonit } \\
\text { from 8/16 sort }\end{array}$ & $\begin{array}{c}\text { 0\% LiDonit } \\
\text { from 8/16 sort }\end{array}$ & $\begin{array}{c}\text { Minimum } \\
\text { required [mm] }\end{array}$ \\
\hline $\begin{array}{c}\text { Workability } \\
\text { [mm] }\end{array}$ & 160 & 180 & 160 & 155 & 155 & $50-150$ \\
\hline CEM III/A & $\begin{array}{c}\mathbf{1 0 0 \% ~ L i D o n i t ~} \\
\text { from 8/16 sort }\end{array}$ & $\begin{array}{l}\mathbf{7 5 \%} \text { LiDonit } \\
\text { from 8/16 sort }\end{array}$ & $\begin{array}{c}\mathbf{5 0 \%} \text { LiDonit } \\
\text { from 8/16 sort }\end{array}$ & $\begin{array}{c}\text { 25\% LiDonit } \\
\text { from 8/16 sort }\end{array}$ & $\begin{array}{c}\text { 0\% LiDonit } \\
\text { from 8/16 sort }\end{array}$ & $\begin{array}{c}\text { Minimum } \\
\text { required [mm] }\end{array}$ \\
\hline $\begin{array}{c}\text { Workability } \\
\text { [mm] }\end{array}$ & 120 & 135 & 145 & 155 & 150 & $50-150$ \\
\hline
\end{tabular}

As for the density measurements, presented in Table 2, for the same sample types as for the workability tests, results show a decrease in density for almost all samples with higher than $25 \%$ LiDonit content out of the $8 / 16 \mathrm{~mm}$ aggregate sort. Although the values are small enough for the samples to be considered acceptable, the obtained results indicate a certain increase in volume for the samples with higher LiDonit content. Again, as for the workability test, the indicated LiDonit content is also considered optimum between $25-50 \%$ out of the $8 / 16 \mathrm{~mm}$ aggregate sort, from the density point of view.

Table 2. Density test results for all mixtures

\begin{tabular}{|c|c|c|c|c|c|c|}
\hline CEM II/A-V & \begin{tabular}{|l}
$100 \%$ LiDonit \\
from $8 / 16$ sort
\end{tabular} & $\begin{array}{l}75 \% \text { LiDonit } \\
\text { from } 8 / 16 \text { sort }\end{array}$ & \begin{tabular}{|l|}
$50 \%$ LiDonit \\
from $8 / 16$ sort
\end{tabular} & \begin{tabular}{|c|}
$25 \%$ LiDonit \\
from $8 / 16$ sort
\end{tabular} & \begin{tabular}{|c|} 
\%\% LiDonit \\
from $8 / 16$ sort
\end{tabular} & $\begin{array}{c}\text { Planned } \\
{\left[\mathrm{kg} / \mathrm{m}^{3}\right]}\end{array}$ \\
\hline $\begin{array}{c}\text { Fresh concrete } \\
{\left[\mathrm{kg} / \mathrm{m}^{3}\right]}\end{array}$ & 2349 & 2337 & 2332 & 2327 & 2340 & 2413 \\
\hline $\begin{array}{c}\text { Hardened } \\
\text { concrete } \\
{\left[\mathrm{kg} / \mathrm{m}^{3}\right]}\end{array}$ & 2383 & 2361 & 2353 & 2326 & 2320 & 2400 \\
\hline \begin{tabular}{|c|} 
Difference \\
between fresh \\
and hardened \\
concrete \\
{$\left[\mathrm{kg} / \mathrm{m}^{3}\right]$} \\
\end{tabular} & -34 & -24 & -21 & 1 & 20 & 13 \\
\hline CEM III/A & $\begin{array}{l}100 \% \text { LiDonit } \\
\text { from } 8 / 16 \text { sort }\end{array}$ & $\begin{array}{l}75 \% \text { LiDonit } \\
\text { from } 8 / 16 \text { sort }\end{array}$ & \begin{tabular}{|c|}
$50 \%$ LiDonit \\
from $8 / 16$ sort
\end{tabular} & \begin{tabular}{|l|}
$25 \%$ LiDonit \\
from $8 / 16$ sort
\end{tabular} & \begin{tabular}{|c|}
$0 \%$ LiDonit \\
from $8 / 16$ sort
\end{tabular} & $\begin{array}{c}\text { Planned } \\
{\left[\mathrm{kg} / \mathrm{m}^{3}\right]}\end{array}$ \\
\hline \begin{tabular}{|c|} 
Fresh concrete \\
{$\left[\mathrm{kg} / \mathrm{m}^{3}\right]$} \\
\end{tabular} & 2379 & 2349 & 2379 & 2327 & 2380 & 2413 \\
\hline $\begin{array}{c}\text { Hardened } \\
\text { concrete } \\
{\left[\mathrm{kg} / \mathrm{m}^{3}\right]}\end{array}$ & 2400 & 2360 & 2352 & 2324 & 2340 & 2400 \\
\hline \begin{tabular}{|c|} 
Difference \\
between fresh \\
and hardened \\
concrete \\
{$\left[\mathrm{kg} / \mathrm{m}^{3}\right]$}
\end{tabular} & -21 & -11 & 27 & 3 & 40 & 13 \\
\hline
\end{tabular}

Hardened samples of concrete, with various content of LiDonit replacing the aggregate, were tested for the compression strength (Figures 5 and 6), after 7 and 28 curing days. This test demonstrated that aggregate replacement with LiDonit may be feasible for concrete recipes using some type of cements. In this case, the samples obtained using CEM II/A-V type cement registered higher values of compression strength for all (after 7 or 28 curing days) LiDonit contents, compared with the samples obtained using CEM III/A type cement. Moreover, for the samples obtained using the CEM III/A type cement, after 7 curing days, only the one with $25 \%$ of LiDonit as replacement for the $8 / 16 \mathrm{~mm}$ aggregate sort, obtained a compression strength value higher than the minimum required, while the other samples registered lower values. For the same type of concrete samples, after 28 curing days, all samples with LiDonit content registered values lower than the minimum required. On the other hand, for all samples obtained using CEM II/A-V type cement, the compression strength results were above the 
minimum required with values decreasing with LiDonit content increase. The value for the compression strength test closest to the one of the LiDonit free sample was registered for the $25 \%$ replacement of $8 / 16 \mathrm{~mm}$ aggregate sort, making this content the preferable one proposed for the samples using CEM II/A-V type cement.

Compression strength after 7 days

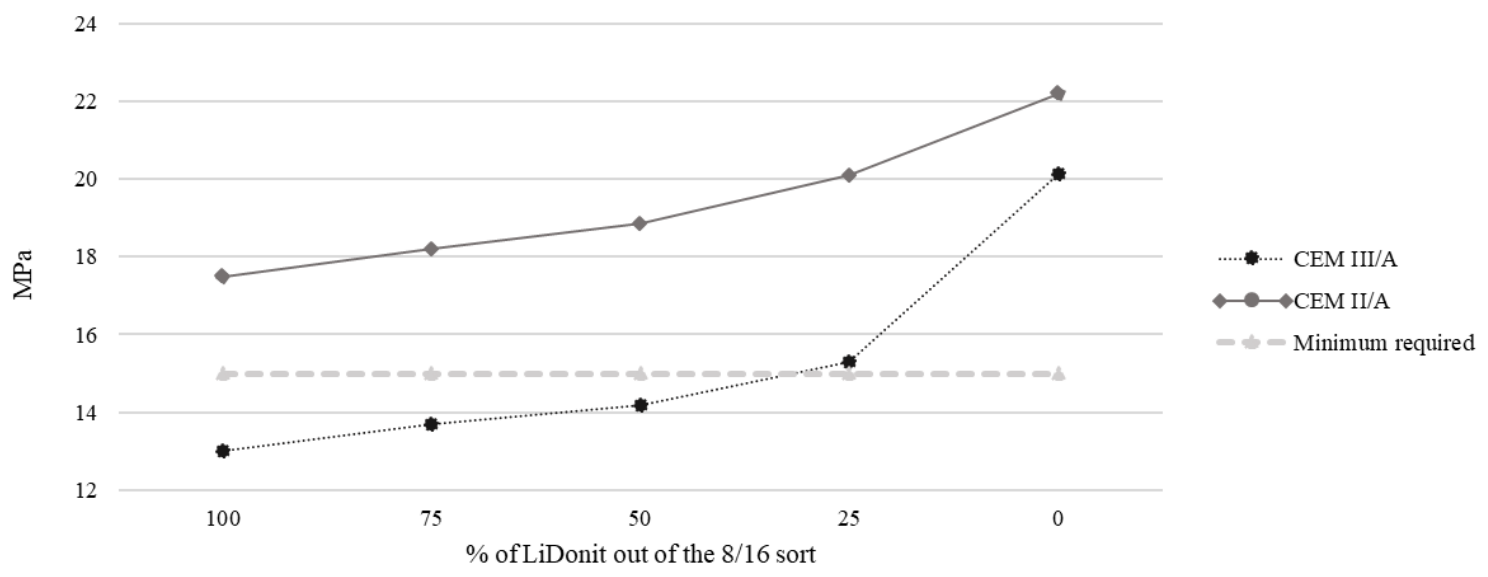

Fig. 5. Compressive strength test for all mixtures after 7 days curing

Compression strength after 28 days

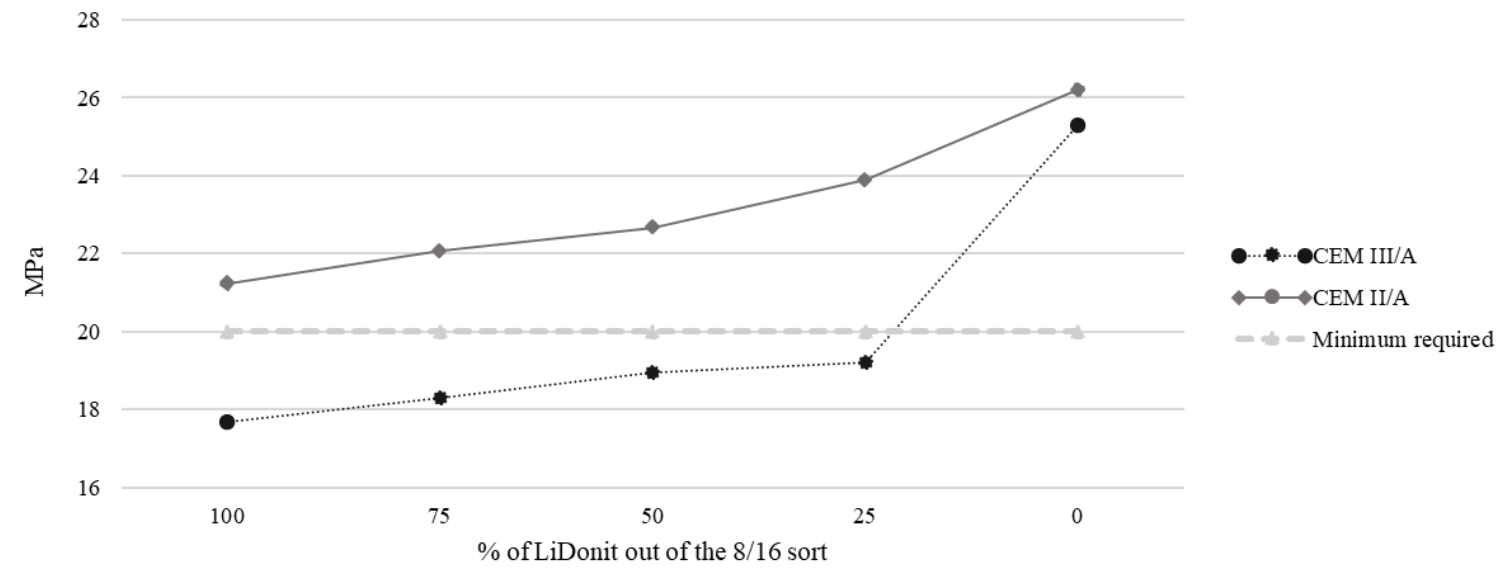

Fig. 6. Compressive strength test for all mixtures after 28 days curing

Further tests were performed to observe the possibility of LiDonit utilization as aggregate replacer namely impermeability and freezing-thaw resistance tests. Results of these tests are presented in Tables 35. The samples used for these tests were obtained using only the CEM II/A-V type cement, since samples using this type of binder behaved within standard limits for all earlier tests. As for the LiDonit content, for these two last tests, only a $100 \%$ LiDonit replacement of $8 / 16 \mathrm{~mm}$ aggregate sort and a $100 \%$ gravel out of the $8 / 16 \mathrm{~mm}$ aggregate sort were used. Again, for both later tests, blocks of $150 \times 150 \times 150$ $\mathrm{mm}$ samples were used. Regarding the impermeability test, results showed a higher water penetration for the LiDonit containing samples (an average of $38 \mathrm{~mm}$ compared to an average of $21 \mathrm{~mm}$ ) yet well within the admissible limit of $100 \mathrm{~mm}$. Therefore, one can only extrapolate, and will certainly obtain a smaller value for the samples containing $25 \%$ LiDonit content out of the $8 / 16 \mathrm{~mm}$ aggregate sort, which was stated to be the preferred case for the concrete using CEM II/A-V type cement.

From the last test performed we retrieved different types of data (initial/final mass, initial/final dimensions, compressive force, section surface, initial/final density, compression strength, observed and expected loss in resistance) from which we can observe small differences between the two samples analysed. The most important values from this test are considered to be the ones from the observed and 
expected loss in resistance. As expected, this loss in resistance is infimal for the samples containing $100 \%$ gravel out of the $8 / 16 \mathrm{~mm}$ aggregate sort. Also, a small difference $(3.90 \%$ for LiDonit containing sample, compared to $2.20 \%$ for gravel containing sample) and well below the maximum accepted value (25\%), was obtained for the LiDonit containing sample. Once again, one can only extrapolate a loss in resistance value for a sample with less LiDonit content.

Table 3. Impermeability test results for the most relevant concrete mixtures

\begin{tabular}{|c|c|c|c|c|}
\hline CEM II/A-V & & Sample 1 & Sample 2 & Sample 3 \\
\hline \multirow{4}{*}{$\begin{array}{c}100 \% \\
\text { LiDonit 8/16 } \\
\text { mm sort }\end{array}$} & $\begin{array}{c}\text { Sample dimensions } \\
{[\mathrm{mm}]}\end{array}$ & $150 \times 150 \times 150$ & $150 \times 150 \times 150$ & $150 \times 150 \times 150$ \\
\hline & $\begin{array}{c}\text { Limit of depth } \\
\text { penetration }[\mathrm{mm}]\end{array}$ & 100 & 100 & 100 \\
\hline & $\begin{array}{l}\text { Depth penetration of } \\
\text { water in sample [mm] }\end{array}$ & 35 & 38 & 41 \\
\hline & $\begin{array}{l}\text { Average of water } \\
\text { penetration in } \\
\text { samples [mm] }\end{array}$ & \multicolumn{3}{|c|}{38} \\
\hline \multirow{4}{*}{$\begin{array}{l}100 \% \text { Gravel } \\
8 / 16 \text { mm sort }\end{array}$} & $\begin{array}{c}\text { Sample dimensions } \\
{[\mathrm{mm}]}\end{array}$ & $150 \times 150 \times 150$ & $150 \times 150 \times 150$ & $150 \times 150 \times 150$ \\
\hline & $\begin{array}{c}\text { Limit of depth } \\
\text { penetration [mm] }\end{array}$ & 100 & 100 & 100 \\
\hline & $\begin{array}{c}\text { Depth penetration of } \\
\text { water in sample [mm] }\end{array}$ & 25 & 21 & 17 \\
\hline & $\begin{array}{l}\text { Average of water } \\
\text { penetration in } \\
\text { samples [mm] }\end{array}$ & \multicolumn{3}{|c|}{21} \\
\hline
\end{tabular}

Table 4. Results from the freezing-thaw resistance test (50 cycles) for the sample of concrete containing 100\% LiDonit from 8/16 mm sort and CEM II A-V 42,5R type cement

\begin{tabular}{|c|c|c|c|c|}
\hline & \multicolumn{2}{|c|}{$\begin{array}{l}\text { Witness sample } \\
\text { 100\% LiDonit }\end{array}$} & \multicolumn{2}{|c|}{$\begin{array}{c}\text { Sample used in freezing- } \\
\text { thaw resistance test } \\
100 \% \text { LiDonit }\end{array}$} \\
\hline $\begin{array}{c}\text { Initial mass Mi } \\
{[\mathrm{g}]}\end{array}$ & 7.773 & 7.743 & 7.742 & 7.737 \\
\hline $\begin{array}{c}\text { Final mass } \\
{[\mathrm{g}]}\end{array}$ & 7.785 & 7.755 & 7.729 & 7.726 \\
\hline $\begin{array}{l}\text { Initial dimensions } \\
{[\mathrm{mm}]}\end{array}$ & $150 / 150 / 150$ & $150 / 150 / 150$ & $150 / 150 / 150$ & $150 / 150 / 150$ \\
\hline $\begin{array}{c}\text { Final dimensions } \\
{[\mathrm{mm}]}\end{array}$ & $150 / 150 / 150$ & $150 / 150 / 150$ & $150 / 150 / 150$ & $150 / 150 / 150$ \\
\hline $\begin{array}{c}\text { Compressive force } \\
{[\mathrm{kN}]}\end{array}$ & 571.5 & 580.5 & 477.0 & 479.7 \\
\hline $\begin{array}{c}\text { Section } \\
{\left[\mathbf{m m}^{2}\right]}\end{array}$ & 22500 & 22500 & 22500 & 22500 \\
\hline $\begin{array}{c}\text { Initial density } \\
{\left[\mathrm{kg} / \mathrm{m}^{3}\right]}\end{array}$ & 2303 & 2294 & 2294 & 2292 \\
\hline $\begin{array}{l}\text { Final density } \\
{\left[\mathrm{kg} / \mathrm{m}^{3}\right]}\end{array}$ & 2307 & 2298 & 2290 & 2289 \\
\hline \multirow{2}{*}{$\begin{array}{c}\text { Compression strength } \\
{[\mathrm{MPa}]} \\
\end{array}$} & 23.40 & 23 & 21.20 & 21.32 \\
\hline & \multicolumn{2}{|c|}{ Average result - 23.2} & \multicolumn{2}{|c|}{ Average result -21.26} \\
\hline $\begin{array}{c}\text { Observed loss in resistance } \\
{[\%]}\end{array}$ & \multicolumn{4}{|c|}{3.90} \\
\hline $\begin{array}{c}\text { Expected loss in resistance } \\
{[\%]}\end{array}$ & \multicolumn{4}{|c|}{ Maximum allowed - 25} \\
\hline
\end{tabular}


Table 5. Results from the freezing-thaw resistance test (50 cycles) for the sample of concrete containing $100 \%$ gravel from $8 / 16 \mathrm{~mm}$ sort and CEM II A-V 42,5R type cement

\begin{tabular}{|c|c|c|c|c|}
\hline & \multicolumn{2}{|c|}{$\begin{array}{l}\text { Witness sample } \\
100 \% \text { gravel }\end{array}$} & \multicolumn{2}{|c|}{$\begin{array}{l}\text { Sample used in freezing- } \\
\text { thaw resistance test } \\
100 \% \text { gravel }\end{array}$} \\
\hline $\begin{array}{c}\text { Initial mass Mi } \\
{[\mathrm{g}]}\end{array}$ & 7.890 & 7.850 & 7.820 & 7.830 \\
\hline $\begin{array}{c}\text { Final mass } \\
{[\mathrm{g}]}\end{array}$ & 7.920 & 7.950 & 7.880 & 7.885 \\
\hline $\begin{array}{l}\text { Initial dimensions } \\
{[\mathrm{mm}]}\end{array}$ & $150 / 150 / 150$ & $150 / 150 / 150$ & $150 / 150 / 150$ & $150 / 150 / 150$ \\
\hline $\begin{array}{l}\text { Final dimensions } \\
{[\mathrm{mm}]}\end{array}$ & $150 / 150 / 150$ & $150 / 150 / 150$ & $150 / 150 / 150$ & $150 / 150 / 150$ \\
\hline $\begin{array}{c}\text { Compressive force } \\
{[\mathrm{kN}]}\end{array}$ & 585 & 580.5 & 585 & 590 \\
\hline $\begin{array}{l}\text { Section } \\
{\left[\mathrm{mm}^{2}\right]}\end{array}$ & 22500 & 22500 & 22500 & 22500 \\
\hline $\begin{array}{c}\text { Initial density } \\
{\left[\mathrm{kg} / \mathrm{m}^{3}\right]}\end{array}$ & 2337 & 2326 & 2317 & 2320 \\
\hline $\begin{array}{c}\text { Final density } \\
{\left[\mathrm{kg} / \mathrm{m}^{3}\right]}\end{array}$ & 2347 & 2355 & 2334 & 2336 \\
\hline \multirow{2}{*}{$\begin{array}{c}\text { Compression strength } \\
{[\mathrm{MPa}]}\end{array}$} & 26.20 & 25.80 & 26 & 26.22 \\
\hline & \multicolumn{2}{|c|}{ Average result - 26} & \multicolumn{2}{|c|}{ Average result - 26.11} \\
\hline $\begin{array}{c}\text { Observed loss in resistance } \\
{[\%]}\end{array}$ & \multicolumn{4}{|c|}{2.20} \\
\hline $\begin{array}{c}\text { Expected loss in resistance } \\
{[\%]}\end{array}$ & \multicolumn{4}{|c|}{ Maximum allowed -25} \\
\hline
\end{tabular}

\section{Conclusions}

Two types of binders were used in this study. The first (CEM II A-V42,5 R) containing 80-94\% Portland clinker and 6-20\% thermal power plant fly ash. The second type (CEM III/A 42,5 N-LN) containing $36-65 \%$ blast furnace granulated slag and Portland clinker as balance. Tests showed a higher need for water in case of samples obtained with CEM III/A type cement than the other one, and a higher value of compression test (approximatively 2-3 MPa) for CEM II/A-V. The two differences, although not important, are clearly a consequence of using industrial wastes in binder production.

Further on, replacement, in various degrees $(100 \%, 75 \%, 50 \%$ and $25 \%)$, of $8 / 16 \mathrm{~mm}$ aggregate sort (out of natural $0 / 4 \mathrm{~mm}, 4 / 8 \mathrm{~mm}$ and $8 / 16 \mathrm{~mm}$ aggregate materials) with LiDonit (a steelmaking byproduct) was realised for multiple tests. Regarding the granulometric curve for all aggregates, all mixtures (with or without LiDonit content) fell between the admissible limits. For all the other tests (water absorption, water to cement ratio, density, compression strength, wear resistance and freezingthaw resistance), the increase of LiDonit content as
$8 / 16 \mathrm{~mm}$ aggregate replacer, resulted in gradually worsening values for the tested samples.

Although LiDonit presents a higher porosity than the natural $8 / 16 \mathrm{~mm}$ aggregate, its crystalline mineralogical content makes it good at impact and compression tests. Also, its obtaining from crushed raw slag leads to polyhedral-shaped granules with sharp edges and corners and many rough faces (apparently a drawback) which along with a higher density develops an important property, namely auto compaction. Thus, although in high amounts the properties of samples are worsened, we can conclude that for some concrete types (using CEM II/A-V in the present study) the replacement of, at least, 8/16 $\mathrm{mm}$ aggregate sort is feasible in amounts of $25 \%$. This percentage of aggregate replacement with LiDonit and the replacement of 6-20\% Portland clinker, from cement obtaining, with thermal power plant fly ash, makes this concrete recipe feasible, to be used at least in foundations works, and more environmentally friendly.

Further work regarding aggregate replacement with LiDonit in concrete, might be focused on using binders containing 100\% Portland clinker. Also, other steel industry by-products might be used as aggregate replacement and all aggregate dimensions can be targeted. 


\section{References}

[1]. Marinela Bărbuță, Betoane de Ciment cu Agregate din Zgură de Oţelărie (Lidonit), Institutul Politehnic Iaşi - Facultatea de Construcții https://docplayer.net, 2017.

[2]. ***, http://cyd.ro/valorificarea-zgurilor-siderurgice/ - accesat în data de 05.05.2017.

[3]. ***, http://www.euconstructor.ro/betonul-din-zgura/ -accesat în data de 05.05.2017.

[4]. Marius Bodor, Rafael M. Santos, Geanina Cristea, Salman Muhammad, Özlem Cizer, Remus Ion Iacobescu, Yi Wai Chiang, Koenrad Van Balen, Maria Vlad, Tom Van Gerven, Laboratory investigation of carbonated BOF slag used as partial replacement of natural aggregate in cement mortars, Cement and Concrete Composites Journal, 65, p. 55-66, 2016.

[5]. Marius Bodor, Rafael M. Santos, Lubica Kriskova, Jan Elsen, Maria Vlad, Tom Van Gerven, Susceptibility of mineral phases of steel slags towards mineral carbonation: mineralogical, morphological and chemical assessment, European Journal of Mineralogy, vol. 25, no. 4, p. 533-549, 2013.

[6]. Rafael M. Santos, Marius Bodor, Paul N. Dragomir, Andreea G. Vraciu, Maria Vlad, Tom Van Gerven, Magnesium chloride as a leaching-and aragonite-promoting additive for the mineral carbonation of calcium-rich materials, Minerals Engineering Journal, vol. 59, p. 71-81, 2014.

[7]. Marius Bodor, Rafael M. Santos, Yi Wai Chiang, Maria Vlad, Tom Van Gerven, Impacts of nickel nanoparticles on mineral carbonation, The Scientific World Journal, vol. 2014, article ID 921974, 10 pages, 2014.

[8]. Marius Bodor, Rafael M. Santos, Tom Van Gerven, Susceptibility of main mineral phases of steel slags towards mineral carbonation and calcium leaching, SGEM 2015, Albena, Bulgaria, Volumul Energy and Clean Technologies (Conference proceedings), p. 817-823, ISBN 978-619-7105-38-4, 18-24 Iunie 2015.

[9]. ***, https://www.thyssenkrupp.com/en/newsroom/pressreleases/press-release-47861.html.

[11]. Gugiuman Gh., Silviu Cristian Iriciuc, The use of steel works crushed slag (lidonit) in the preparation of asphalt mixtures, Buletinul Institutului Politehnic din Iași, Tomul L (LIV), Fasc. 1-4, 2004.

[10]. Licuța Cristea, Marian Badiu, Doina Iofcea, Utilizarea agregatelor lidonit în domeniul constructiilor $\hat{\imath}$ România, https://docplayer.net/78324283-Utilizarea-agregatelor-lidonit-indomeniul-constructiilor-in-romania.html.

[12]. ***, SR EN 12620+A1: 2008, Agregate pentru beton.

[13]. ***, DSU launches new mineral material for asphalt road surfaces, Thyssenkrupp, Products and solutions, 2002.

[14]. ***, SR EN 12350-1:2003, Incercări beton proaspăt.

[15]. ***, Agreement tehnic nr. 004-07/431-2001, Agregate din zgură de oţelărie.

[16]. ***, SR 183-1/1995, Lucrări de drumuri. Îmbrăcăminţi de beton de ciment executate în cofraje fixe.

[17]. ***, STAS 1275-88, Încercări pe betoane. Incercări pe betonul întărit. Determinarea rezistenţelor mecanice.

[18]. ***, EN 206-1 - Beton. Partea 1: Specificție, performanță, producție şi conformitate.

[19]. ***, EN 15167-1: 2006, Title: ground granulated blast furnace slag for use in concrete, mortar and grout - part 1: definitions, specifications and conformity criteria.
[20]. ***, CEN/TC 104/SC1 N717, Use of $k$-value concept, equivalent of concrete performance concept and equivalent, 2011. [21]. ***, CP 012/1-2007, Normativ pentru producerea betonului şi executarea lucrărilor din beton, beton armat şi beton precomprimat-Partea 1: Producerea betonului.

[22]. ***, NE 012/2 - 2010, Normativ pentru producerea betonului şi executarea lucrărilor din beton, beton armat şi beton precomprimat - Partea 2: Executarea lucrărilor din beton.

[23]. ***, SR EN 450-1:2006, Cenuşă zburătoare pentru beton. Partea 1: Definiţii, condiţii şi criterii de Conformitate.

[24]. ***, C 215-88, Instrucţiuni tehnice pentru elemente de fundaţii din beton cu adaos de cenuşă de centrale termoelectrice situate în terenuri cu agresivităţi naturale şi industriale.

[25]. ***, SR EN 197-1:2011, Ciment. Partea 1: Compoziţie, specificaţii şi criterii de conformitate ale cimenturilor uzuale.

[26]. ***, SR EN 197-1/A1: 2004, Ciment. Partea 1: Compoziţie, specificaţii şi criterii de conformitate ale cimenturilor uzuale. Amendament 1: Ciment Portland cu zgură cu căldură de hidratare redusă.

[27]. ***, SR EN 197-2:2002, Ciment. Partea 2: Evaluarea conformităţii.

[28]. ***, SR EN 196-1:2006, Metode de incercări ale cimenturilor. Partea 1: Determinarea rezistenţelor mecanice.

[29]. ***, SR EN 196-3:2006, Metode de incercări ale cimenturilor. Partea 3: Determinarea timpului de priză şi a stabilităţii.

[30]. ***, SR EN 197-4:2004, Ciment. Compoziţie, specificaţii şi criterii de conformitate pentru cimenturi de furnal cu rezistenţă iniţială mică.

[31]. ***, SR EN 196-7:1995, Metode de incercări ale cimenturilor. Metode de prelevare şi pregătire a probelor de ciment.

[32]. ***, STAS 4606-80, Agregate naturale grele pentru betoane şi mortare cu lianţi minerali. Metode de incercare.

[33]. ***, SR EN 933-1:2002, Incercări pentru determinarea caracteristicilor generale ale agregatelor. Partea 1: Determinarea granulozităţii. Analiza granulometrică prin cernere.

[34]. ***, SR EN 933-4:2002, Încercări pentru determinarea caracteristicilor generale ale agregatelor. Partea 4: Determinarea formei particulelor. Coeficient de formă.

[35]. ***, SR EN 1367-1:2002, Incercări pentru determinarea caracteristicilor termice şi de alterabilitate ale agregatelor. Partea 1: Determinarea rezistenţei la îngheţ-dezgheţ.

[36]. ***, SR ISO 565:1997, Site de cernere. Țesături metalice, table metalice perforate şi folii electroperforate. Dimensiuni nominale ale ochiurilor.

[37]. ***, SR EN 1008-2003, Apa de preparare pentru beton. Specificaţii pentru prelevare, incercare şi evaluare a aptitudinii de utilizare a apei, inclusiv apelor recuperate din procese ale industriei de beton, ca apă de preparare pentru beton.

[38]. ***, SR EN 934-2:2003, Aditivi pentru beton, mortar şi pastă. Partea 2: Aditivi pentru beton. Definiţii, condiţii, conformitate, marcare şi etichetare.

[39]. ***, SR EN 934-6:2005, Aditivi pentru beton, mortar şi pastă. Partea 6: Eşantionare, control şi evaluare a conformităţii.

[40]. ***, SR EN 12390-5:2009, Incercare pe beton întărit. Partea 5: Rezistenţa la încovoiere a epruvetelor.

[41]. ***, SR 3518-2009, Incercări de laborator ale betoanelor. Determinarea rezistenţei la îngheţdezgheț. 